\title{
RURAL TOURISM IN THE FUNCTION \\ OF RURAL AREAS DEVELOPMENT \\ IN THE REPUBLIC OF SERBIA
}

\author{
Branko Mihailović ${ }^{1}$ (C) \\ Vesna Popović ${ }^{2}$
}

DOI: https://doi.org/10.31410/tmt.2019.251

\begin{abstract}
The development of rural tourism based on the individualization of tourist demand and its focus on non-standard tourism products provides one of the key contributions to rural development. The paper discusses the possibility of developing rural tourism in Serbia and key factors for the success of rural economy diversification through rural tourism, primarily synergetic effects of agriculture and tourism, and thus established local value chains, introduction of food quality standards, application of information technologies, efficient management of tourist destination and adequate financial support, especially to small businesses in rural tourism. Lack of an integrated tourist offer makes it difficult to apply marketing and management approaches to rural tourism development at the national level and the level of local rural tourism destinations and this must be given special attention in the future.
\end{abstract}

Keywords: Rural Tourism, Rural Areas, Rural Economy, Diversification.

\section{INTRODUCTION}

$\mathrm{A}$ ccording to the definition of the World Tourism Organization (UNWTO), ,rural tourism is a type of tourism activity in which the visitor's experience is related to a wide range of products generally linked to nature-based activities, agriculture, rural lifestyle / culture, angling and sightseeing. Rural tourism activities take place in non-urban (rural) areas with the following characteristics:

- low population density,

- landscape and land-use dominated by agriculture and forestry, and

- traditional social structure and lifestyle" (UNWTO, 2017a, 2017b).

Europe was, since the '50s of the past century, the first region to develop a coherent understanding of Rural Tourism. In other parts of the world, similar concepts appeared by the end of the 20 th century in the context of sustainable tourism and community development. They generate considerable domestic markets that have a high potential for future international travel (The ECRT, 2018). Interest in rural tourism is growing in developed tourism countries. Research conducted on the European market indicates that in the mid-nineties $9 \%$ of tourists were targeting rural destinations. On the UK market, as much as $25 \%$ of tourists showed interest in staying in rural areas (Čomić, 2002).

European rural tourism in 2018 provides around 6 million bed spaces in 500,000 establishments, representing around $15 \%$ of the total accommodation capacity of Europe. Together with related services, the sector generates more than $€ 100$ billion in direct spending - mostly in the local economy - and is a critical element for the vitality of many rural areas (The ECRT, 2018). Rural tour-

\footnotetext{
$1 \quad$ Institute of Agricultural Economics, Volgina Street no. 15, 11060 Belgrade, Serbia

2 Institute of Agricultural Economics, Volgina Street no. 15, 11060 Belgrade, Serbia
} 
ism is much more than farm or agricultural diversification - it is the rural economy diversification efforts to develop rural economy from primary manufacturing-based into the service-based economy. The EU structural, cohesion, rural development and other territorial development policies provide significant support to this transformation of the rural economy (Bojnec, 2010).

The Republic of Serbia has attractive natural and cultural resources, which have great potential for the development of rural tourism. According to data contained in the Program for the development of sustainable rural tourism in the Republic of Serbia (Official Gazette of the RS, $85 / 11$ ), rural tourism is supported with more than 32,000 beds, registered and unregistered, in rural areas, of which 10,000 beds are exclusively in villages and in 2010 generated revenue of 10.4 billion dinars in direct spending (16\% of GDP realized in the travel and tourism sector, according to the WTTC Travel and Tourism Economic Impact Serbia 2010).

This tourism product should be made recognizable and the financing of entrepreneurial ideas facilitated, taking into account its positive effects, among which are:

1. increase of employment of local population,

2. additional income for rural households,

3. development of production and service activities;

4. prevention of village-city migration,

5. protection and preservation of natural and cultural heritage; and

6. integral development of rural areas (Hopić, 2010).

\section{MATERIALS AND METHODS}

Several scientific papers, projects' reports and official documents of UNWTO and national and EU institutions and organizations, examining rural tourism and its role in rural economy diversification, are consulted and quoted. The analysis of support measures to the development of rural tourism in Serbia are based on national and EU legislation. During the discussion and formulation of conclusions and recommendations, the analytical-synthetic method was used.

\section{RURAL REGIONS IN SERBIA AND NATURAL ENVIRONMENT}

The development of rural areas is closely linked to the development of agriculture and processing of agricultural products, so agricultural production is traditionally the most important sector of the rural economy and the main source of income for the rural population. Accordingly, investments are needed in the development of micro-enterprises in the field of agricultural products processing, as well as in raising the value of products by obtaining geographical indications.

Investing in the aforementioned activities would improve the competitiveness of agricultural farms in the market, increase the farms' income and improve their economic position, thereby improving the quality of life in rural areas and reducing the rate of depopulation of rural areas. Conditions that would contribute to the employment of the rural population are the strengthening of entrepreneurship and the development of micro-enterprises.

In order to improve the competitiveness of the agricultural sector and stimulate rural development in Serbia, it is necessary to implement adequate strategic measures and projects in the field of human resources improvement. Activities in this area include, first and foremost, greater integration of science and practice through reorganized agricultural stations, advisory 
services, home services, agricultural cooperatives and other farmers' associations; development and implementation of new knowledge and skills of farmers through advice, training, seminars, courses; support for young farmers in modernizing the farm. All projects in this area must be based on adequate government support (financial, advisory, logistical) and coordinated public and private sector activities (Mihalović, Simonović, 2016).

According to the Program on Amendments to the IPARD Program for the Republic of Serbia for the period 2014-2020 (Official Gazette of the RS, 20/19), rural territory of the Republic of Serbia accounts for $75.1 \%$ of the state territory and covers $49.9 \%$ of the total population ${ }^{3}$.

Taking into account demographic, economic, social and infrastructural features, it can be said that rural areas of Serbia have a high degree of differentiation (Mihailović et. al., 2012). Using cluster analysis to more than 40 indicators, homogeneous rural regions were defined, reflecting the specificity of the rural areas in Serbia (Figure 1).

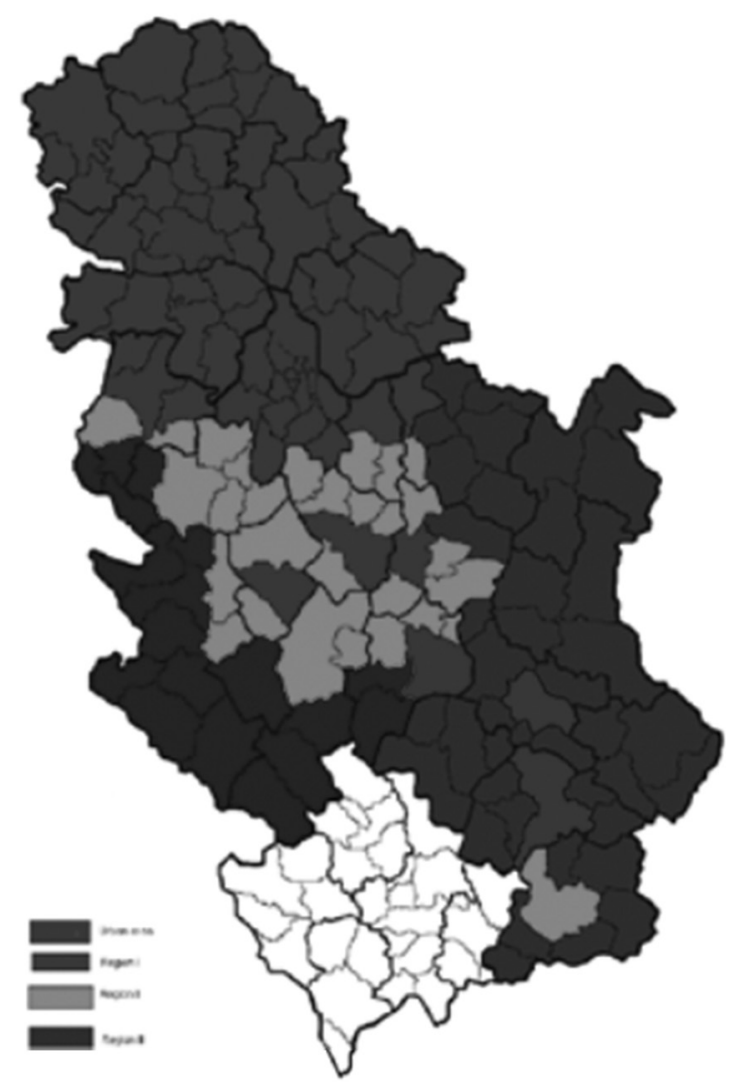

Figure 1. Rural regions in Serbia

Source: NRDP 2011-2013, OG RS, 15/11.

Region of highly intensive agricultural production and integrated economy - covers the territory of Vojvodina and the northwestern part of Serbia (Mačva). This region is characterized by fertile lowlands and significant water resources of large rivers (Danube, Sava and Tisa). The agricultural sector is characterized by intensive production of cereals and oilseeds, developed animal husbandry, vertical integration with the food industry and the dual structure of farms. Higher concentration of population, stronger investment activity and more dynamic economic growth are registered in the western part of the region.

3 Rural areas defined according to the OECD criteria at the municipal level with a population density of less than 150 inhabitants per $\mathrm{km}^{2}$. 
The region of small urban economies with intensive agriculture - includes the northern parts of Central Serbia, Sumadija, parts of Macva and Stig. The area is surrounded by large urban centers, which affects demographic, economic, infrastructural and social trends. Hilly relief prevails, with the mountains in the western and eastern edge of the region. The agricultural sector is dominated by farm size 3-10 ha, highly productive fruit and wine production and developed livestock farming.

Mountainous region, with an economy based on natural resources - extends in the east and south of the country and comprises predominantly mountainous area. In the valleys of the Danube, South Morava and Timok there are lowland areas with diversified economy and agriculture. The region has a low population density, unfavorable age and educational structure of the population and underdeveloped local infrastructure. Agriculture is focused on growing fruits, grapes, cattle and sheep. Natural potentials for cultivation and collection of medicinal herbs, collection of forest fruits and organic production have not been sufficiently exploited.

Region of high tourism potential with a poor agricultural structure - includes the mountainous area of western Serbia. Rural economy is characterized by hydropower potential, tourist facilities and agricultural structure based on a small number of products (raspberry, pasture-based animal husbandry). This region has the greatest potential for successful positioning of a number of tourist products of Serbia, due to an exceptional combination of tradition, history and natural beauty.

Considering the analyzed characteristics of rural regions in Serbia, the dominant causes of their slow development are: migration of rural population, unfavorable age structure, insufficient investments in rural areas, identification of agriculture with the development of rural areas, etc. (Cvijanović et. al., 2012). The structure of employment and income of the rural population indicates that in Serbia the distress-push income diversification is dominant, reflecting the unfavorable economic environment and rural poverty (Bogdanov, 2007). According to the UNDP research (2010), the highest degree of diversification of agricultural incomes have holdings in Western Serbia, and the smallest farms in Vojvodina (Cvejić et al., 2010).

In economic activities such as agriculture, mining and construction, natural conditions exert a strong (decisive) influence on the development of these activities (Pejanović, 1993, pp. 2032). Under natural conditions, qualitative and quantitative characteristics of a given natural environment are meant. These include: climatic conditions, mineral and water resources, soil fertility, wildlife, soil stability. In the history of human society so far, human activity on natural conditions has reached such negative proportions that through the pollution of the natural environment the survival of human existence is endangered.

Land as a basic tool for work and the object of work in agriculture has suffered and is undergoing significant changes both in its use and in its intensity of degradation. The causes of soil degradation are multiple: biological, chemical and mechanical. In the group of chemical pollutants of the earth, a special place is given to the emission of gases which leads to acidification of the soil with acid rain. Forms of physical and chemical soil damage are represented on the surfaces in the surrounding areas of river flows and lakes with pronounced fluctuations in water levels. Industrial and municipal water, followed by agricultural wastewater, especially livestock farms, are a major source of soil pollution.

In addition to soil erosion, a serious problem is the unplanned and uncontrolled change in agricultural land use. Quality arable land is being increasingly used for construction of large in- 
frastructure (roads, railways, airports), industrial and agricultural processing facilities, housing and so on. Systematic inappropriate land use has changed the ecological production conditions of the land. The use of mineral fertilizers, in addition to its basic function and effects, causes undesired physic-chemical and biological changes. A particular danger is the irrational and technologically inadequate application of nitrates with illicit effects on wildlife, soil and water, as well as the uncontrolled use of crop protection products.

However, given the aforementioned increase in the emission of harmful substances into nature, numerous movements, organizations, etc., have appeared in the world, who want to protect it. In this regard, they urge and take appropriate action for the state to intervene, that is, the appropriate international institutions (Cvijanović et al., 2011, p. 43).

The natural environment is made up of natural resources that are necessary for manufacturers or tourism companies as a basis for planning visits to certain destinations, and whose dominant feature is the natural preservation of the environment (Cvijanović, Vuković, 2012, p. 48).

Today's natural and ecological environment is characterized by (Cvijanović, Vuković, 2012, p. 48):

- a universal movement known in the literature as „envoymerism”, which is based on raising awareness of the need to conserve and enhance natural resources and environments;

- education of all age structures in the population on the importance, maintenance and improvement of the quality of the natural environment;

- continuous monitoring of the natural environment for preventative actions in the event of their disturbance;

- undertaking appropriate activities to improve the quality of the environment. For example, placing filters on factory effluents or chimneys, or perhaps stocking up those river or lake water areas where biodiversity is affected, etc.

- preservation of cultural and historical heritage, anthropogenic resources that are integrated with the natural environment, which are the subject of tourist visits, etc.

\section{POSSIBILITIES FOR DEVELOPMENT OF RURAL TOURISM IN SERBIA}

Reformed rural development policy indicates that the EU's strategic approach is to improve the implementation of rural development support programs and to increase its focus on employment, competitiveness and innovation in rural areas. Reformed rural development policy has set the LEADER initiative as a leading approach in the distribution of support and has greatly simplified procedures (Bogdanov, 2007, p. 47). The new rural development policy is in line with the declaration of the Guiding Principles for Sustainable Development (these principles require balance and complementarity between the economy, the environment and society.

A large number of different natural-geographical units and their preserved ecosystem, multiethnicity, local specialties, old crafts, ambient and cultural values and the spiritual heritage of the villages are the basis for establishing a rich rural tourism offer. It is exactly tourism and its multiplicative effects that positively influence the economy of these areas (Vujović et. al., 2012; Đorđević Milošević, Milovanović, 2012).

Rural tourism is one of the key tourism products in 12 out of 18 tourist destinations in Serbia, as defined by the Tourism Development Strategy 2016-2025 (Official Gazette of the RS, 98/16). 
According to the Law on Tourism (Official Gazette of the RS, 17/19), the development of tourism products of particular interest (including rural tourism) is more closely determined by the Tourism Product Development Program, adopted by the Government.

The National Rural Tourism Master Plan, developed in collaboration of UNWTO and other 4 UN agencies participating in the Joint Programme (UNDP, UNFAO, UNEP and UNICEF), line ministries, TOS and local stakeholders, and adopted by the Government ${ }^{4}$ proposes to focus on 12 Rural Tourism Clusters (RTCs) within 4 Groups of Rural Tourism Clusters (RTCGs):

1. Central Serbia and Western Serbia (1. Golija, 2. Zlatar Zlatibor, 3. Kopaonik, 4. Central Serbia);

2. South Banat and Lower Danube (5. Lower Danube, 6. South Banat);

3. Eastern Serbia (7. Soko Banja, 8. Eastern Serbia, 9. Southeastern Serbia);

4. Vojvodina (10. Fruška Gora, 11. Upper Danube and 12. Northern Serbia) (Fig.2).

Through realized synergy, tourism cluster ensure the quality of tourism products and services, as well as facilitate the introduction of innovations and exchange of knowledge, thus leading to increasing stability of regional economy and improvement of the quality of life of population and visitors (Popović et al., 2012). Key success factors of rural economy diversification through rural tourism are related to (Hyvaerinen, 2019):

- Integration of agriculture and tourism as a lever of rural development (e.g. local value chains), quality standards - with local authenticity, and protection of rural identity and natural-cultural landscapes.

- Efficient system of support for beginners in rural tourism business, cross-sectoral cooperation at all levels, incentives for cooperation and innovation, development of new managerial and entrepreneurial knowledge and skills, effective destination management and marketing and community involvement in the destination management process.

Rural Tourism Clusters are ranked by priority, in order to identify those with the greatest potential for the value chain formation and the lowest risk for return on investment in the development of rural tourism. The following criteria for the comparison of RTC were used:

a) potential of natural, cultural and man-made,

b) resources,

c) seasonality,

d) accessibility and infrastructure,

e) unemployment rate,

f) catering offer and accommodation,

g) capacities,

h) experience in tourism.

The assumption is that tourism, with its many functions and effects, would contribute to the revival of villages and at the same time national economies. Considering the problems of transition in which many European countries are located, it is quite understandable why tourism and investment in it were seen in the 1990s and early millennium as a possible driver of the development of national economies and their rural areas, which were unfair over time neglected.

$4 \quad$ Program for the development of sustainable rural tourism in the Republic of Serbia, Official Gazette of RS, $85 / 11$. 


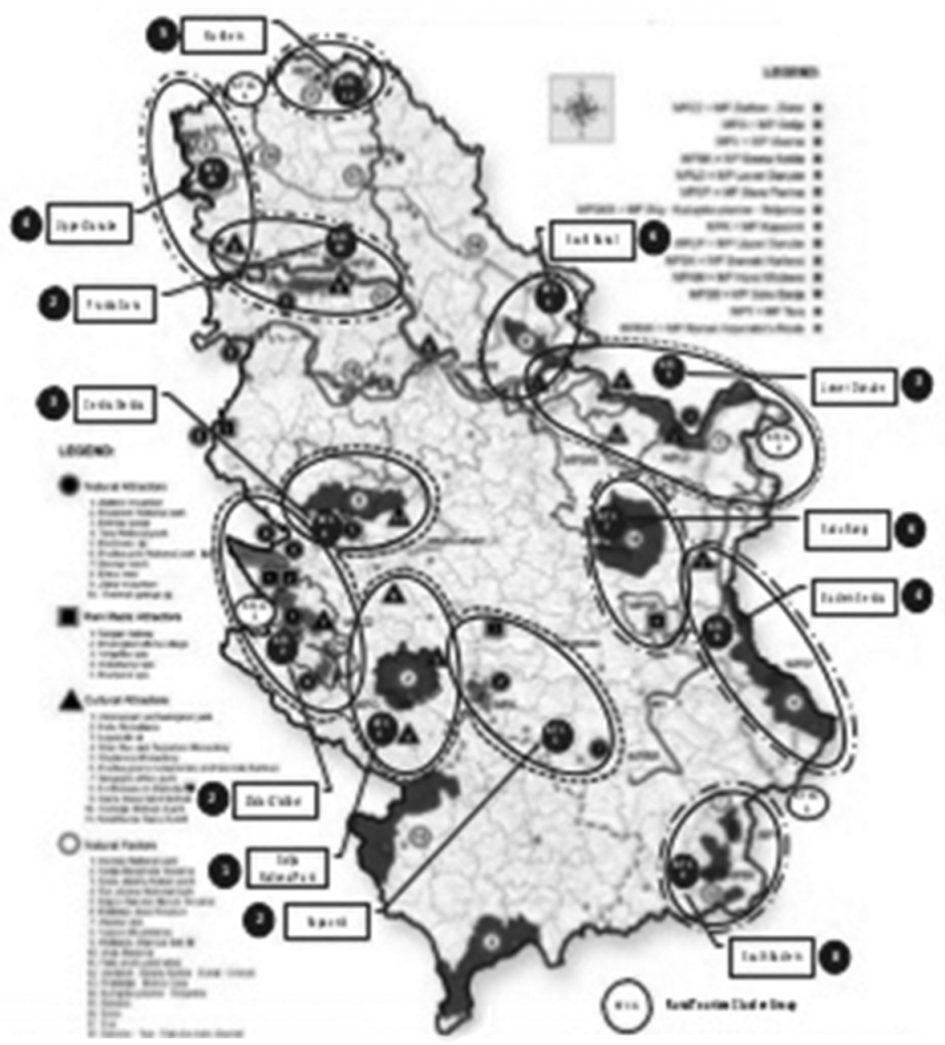

Figure 2. Cross map of factors, attractors, tourism master plans and RTCs in Serbia Source: UNJP in Serbia, (2011).

Accordingly, the development of rural tourism in an unpolluted natural environment, with a pronounced individualization of tourism demand and its more significant focus on non-standard tourism products, is one of the bases for the implementation of the concept of sustainable tourism development. Optimistic estimates of the volume of tourism demand, given above all by UNWTO, imply their positive impact on overall tourism market relations, given the dominant position of demand over tourism supply. In this context, as prevailing tendencies on the side of tourist demand, especially in Europe, we can distinguish (Cvijanović, 2014):

- refreshment through contrast (tourist trips between the lowlands-mountains, city-village, mainland-island, etc.),

- the pursuit of experiences related to cultural and historical heritage and nature conservation, the ,green" movement or tourism, also called alternative, responsible, „soft”, „good” or „new” tourism - refers to both rural tourism; both in cities and on the coast. It implies, first of all, clean water, clean and safe sea, healthy food and unpolluted air, that is tourism that is not massive but „friendly” geared towards the natural environment,

- „blue” or nautical movement, i.e. demand, (cruising by sea using marinas, ports and anchorages),

- demand for places, events and experiences that have a distinct identity, integrity and diversity,

- demand for rural (rural) and agritourism - involves staying in different types of accommodation (not exclusively in rural households) and engaging in activities (sports, adventure, challenges, art, manual labor, etc.),

- demand for health, spiritual, mental and identity renewal - refers to new forms of health or spa tourism: the pursuit of better fitness (recreational activities, sports and exercise, diet, fitness) and the desire for better health through the fight against stress. 


\section{THE ROLE OF FOOD SAFETY AND QUALITY STANDARDS IN RURAL TOURISM DEVELOPMENT}

The development of tourism is an incentive for the improvement of agricultural production, processing and supply of food, as well as the introduction of modern food safety and quality standards (Đorđević Milošević, Milovanović, 2012).

GLOBALG.A.P. is the internationally recognized standard for farm production. GLOBALG.A.P. certification covers food safety and traceability, environment (including biodiversity), workers health, safety and welfare, and animal welfare, and includes Integrated Crop Management (ICM), Integrated Pest Control (IPC), Quality Management System (QMS) and Hazard Analysis and Critical Control Points (HACCP) (GlobalG.A.P., 2019). The Law on Food Safety (Official Gazette of RS, 41/2009, 17/19, Art. 47) prescribes the obligation to establish a food safety system at all stages of production, processing and trade in food, except on the level of primary production in accordance with the principles of good manufacturing and hygiene practice and Hazard Analysis and Critical Control Points (HACCP).

Enrichment of rural tourism offer can be carried out through gastronomy, or the production of local specialties and organic food and its placement through catering industry and at numerous tourist events with culinary content (Šimičević, Štetić, 2011; Popović et al., 2010; Vojnović, 2012). According to the Ministry of Agriculture data for 2017, organic production in Serbia took place on 13,423 ha $(0.38 \%$ of used agricultural land). Vojvodina is the region with the largest share in the total area involved in organic production (45.1\%), followed by South and East Serbia region (33.9\%) and the Sumadija and Western Serbia region (20.7\%). Organic cattle production is less developed, but it has seen growing trends in 2016-2017 (Serbia Organica, 2019).

By linking the origin of products to a particular area, promotion of the area is achieved, and engagement in certification, promotion and quality control contributes to linking business entities in the chain, improving production and securing the revenues of small producers (Popović et al., 2009; Jovićević Simin et al., 2016). There are 42 agricultural and food products on the List of the indications of geographical origin registered in the Intellectual Property Office of the Republic of Serbia. Honey from Homolje and ajvar from Leskovac were registered in accordance with the Lisbon Agreement for the Protection of Appellations of Origin and their International Registration, (MEI, 2018).

A small number of primary agricultural producers in the Republic of Serbia have certificates for GlobalG.A.P., organic production and products with a geographical origin. The improvement of the current situation is expected through the financial and advisory support of the state, with more active role of the associations of producers and cooperatives and the engagement of processors, exporters and traders (Popović et al. 2017). Slightly better is the situation in food processing industry (SEEDEV, 2014).

The quality of agri-food products is a very important aspect of branding. In developed countries, all aspects of agricultural product quality, through standards and laws, are precisely defined, and their respect is the first ticket to enter developed markets. Namely, for food exporters to compete seriously in the world market, they must adopt numerous international and European standards, which will greatly reduce their procedures and access to those markets and remove trade and technical barriers. For example, the document, abbreviated as "HACCP", is a 
worldwide recognized system of "Critical Control Points in Food Production" and is a kind of passport for food exports not only to the EU.

The ultimate goal of this standard is to produce health food in a chain from field to table. In the future, Serbia will have to pay special attention to improving quality and quality control systems. New laws are now to be passed in the areas of quality, namely the Law on Standardization, as well as the harmonization of regulations with EU legal norms. Finally, given that quality is closely linked to technology and technological change, it is clear that changes and harmonization with the world follow us in this segment as well.

Namely, in the modern economy, the advantage is on the side of companies that successfully combine technology and marketing in the strategic mix of business functions of enterprises. So far, the problems of Serbian exporters and competitive appearance on the foreign market are twofold: both from the point of view of the inapplicability of the marketing concept and from the point of view of technological lag.

The product is a very significant instrument in the marketing activity program. In doing so, it is important to distinguish between products intended for direct consumption that are not processed, other than cleaning, sorting and packaging (e.g. fruits, vegetables, eggs) and other groups, consisting of products intended for industrial processing as raw materials (e.g. cereals, sugar beets, cattle, etc.) (Cvijanović et al., 2016).

A good number of products fall into both categories, as they are used both for direct consumption by households and large consumers, and as raw material for industrial processing. In short, the specificity of products in the marketing mix of agricultural products stems from the very specificities of agricultural production, which are the consequence of its biological character.

The production program of agricultural producers is largely conditioned by the nature of the soil, crop rotation, climate, the existence of vegetation periods in crop and livestock production, and taking into account all the above factors, it is necessary to adjust the products to market needs. In addition, since agricultural products are largely homogeneous, there is little scope for product differentiation, especially for those products that represent inputs to the food industry.

However, for those agricultural products sold on green markets and / or through supermarkets, there is a certain possibility of differentiation, first of all, through two important characteristics of the product, namely: packaging and marking (Cvijanović et al., 2016).

\section{INSTITUTIONAL INFRASTRUCTURE AND SUPPORT TO RURAL TOURISM}

According to the Program for development of sustainable rural tourism in the Republic of Serbia (Official Gazette of the RS, 85/11), Destination Management Organization (DMO) is the basis for the operational implementation of the Program. In the Tourism Development Strategy (2016-2025), however, it is noted that the system of management of tourist destinations and areas in the previous period has not been established, and that the development of the DMO and the strengthening of management structures is among the priority activities in tourist destinations.

The development of information technology has enabled the use of a wide range of tools and services that promote tourism business (Vuković et al., 2016). Remote villages have become part 
of a global competition and virtual economy using advanced information and communication technologies in every day businesses, marketing, promotion and similar activities (Bojnec, 2010). However, the unique database of rural tourism supply does not exist in Serbia. Certain efforts in this area makes the National Association of Rural Tourism of Serbia with its www.selo.rs site, designed as a national database of rural tourism offer. The Association provided membership to the European Federation for the Development of Rural Tourism (Eurogites, 2019).

Due to the lack of a unique database of accommodation capacities of rural tourism, monitoring of the number of tourist arrivals and overnight stays was difficult (Vuković, 2017). By transferring and processing data on the market and users of tourist services, new technologies enable a better understanding of the needs of users and increase the ability to provide adequate services (Mihailović, Popović, 2018). Meanwhile, as assessed in the Tourism Development Strategy, the non-implementation of legal obligations and the lack of a system of periodic reporting among the entities involved in the planning and implementation of measures and activities is one of the major constraints for responsible management of the tourism industry in Serbia.

An important role in the improvement of rural tourism in Serbia could play a small business. Creating partial tourism programs deserves support. Financial support to companies, entrepreneurs and farmers for the development of rural tourism is provided by:

- the Ministry of Trade, Tourism and Telecommunications (credit funds for promoting the quality of tourist offer, in accordance with the Regulation on conditions and method of allocation and use of credit funds for promotion of the quality of tourist offer, Official Gazette of RS, 6/19),

- Ministry of Agriculture, Forestry and Water Management (incentives for the promotion of economic activities in the countryside by supporting non-agricultural activities - the development of rural tourism, old and artistic crafts and handicrafts, in accordance with the National Program for Rural Development 2018-2020, Official Gazette of RS, 60/18) ${ }^{5}$,

- IPARD II program 2014-2020 (Official Gazette of the RS, no. 30/16, 84/17, 20/19) (investment support for the development of tourist facilities and services and support for the development of tourist and recreational activities within the measure Diversification of agricultural holdings and business development. The first call for this measure was announced for November 15, 2019, MAFWM, 2019). Common marketing, trainings and small-scale cross-border tourism infrastructure projects within Cross Border Cooperation (CBC) Programmes are being implemented under regional policy and trans-national cooperation IPA II 2014-2020 (MEI, 2019).

In most of its rural areas, Serbia has all the prerequisites for promoting and successfully implementing the concept of local action groups and integrated rural development: richness in the diversity of rural areas, significant natural resources, preserved rural environment, great potential for the development of a wide range of non-agricultural activities in the countryside. On the other hand, there are numerous limitations and weaknesses in the field of rural development: unfavorable production and ownership structure in agriculture, unfavorable business environment for the work of SMEs and entrepreneurs, low support to farmers from the agrarian budget, underdeveloped physical and market infrastructure, lack of entrepreneurial spirit, insufficient connectivity of farmers, high centralization of state administration and restrictions on local

The measure is complementary to IPARD measure "Diversification of agricultural holdings and business development". After accreditation of this measure, support for investment in rural tourism development will not be implemented within NRDP. 
governments in implementing rural development projects. The cultural participation of the rural population is passive and poorly diversified (UNDP, 2010, p.15). The main reasons for poor cultural participation are a lifestyle in which a lot of time is spent on work activities, high material poverty, but also low motivation and disinterest. Although primary schools exist in most villages, pre-schools, cultural centers and libraries are poorly represented, except in Vojvodina.

There are certain regional differences in the consumption of cultural content, which show a slightly more active style of inhabitants of the villages of Vojvodina than others. The social capital of the rural population is low, no matter what region or ethnic group it is, and there is enormous space and a chance to increase the level of social cohesion in rural communities by raising the culture of association (UNDP, 2010, p.15). Relevant local decision-makers in rural Serbia are (Bogdanov, 2007, p. 125):

- Representatives of local self-government (municipal authorities), including regional chambers of commerce, SME agencies, etc.;

- Business sector representatives (SMEs, entrepreneurs, producer associations, agricultural cooperatives);

- Representatives of the non-governmental sector.

Cooperation between these actors is insufficient, uncoordinated and sporadic (Bogdanov, 2007, p. 125). Cooperation with the rural population (members of agricultural holdings) is especially small. High percentage of respondents ( $34 \%$ to be exact) within small rural households points out that no institution is currently working to improve the condition of rural households, and in the inability to recognize other relevant actors and social partners, small rural households have all the responsibility for the current situation in rural areas transfer to the state and government. In the analysis of LAGs, the weaknesses or small capacities of linking farmers to associations and cooperatives should be particularly emphasized. The reasons for the underdevelopment of these forms of association are found on the side of: farmers: (1) an unrealized awareness of the need and benefits of association; (2) farmer mentality (distrust of the state, other farmers; domination of personal and short-term interests over long-term and common); (3) the unequal economic strength and size of the holdings that make it difficult to associate; (4) negative experiences in the functioning of associations / cooperatives; as well as on the side of the state or line ministry: (1) lack of financial, legal and advisory support of the state for the establishment and operation of existing associations / cooperatives; (2) underdeveloped business environment (environment) for engaging in agriculture, processing and non-agricultural activities.

The "Western world" population lives in economies that are increasingly reliant on services. They are no longer a smaller or artificial part of economies, but are at the heart of the value creation process of every economy. Today, most products contain some element of service within them. Activities such as accounting, banking, etc. can be easily identified as a service activity. In addition to these, a wide range of goods relies on service activities that give them a competitive edge. Customers perceive quality quite differently, depending on what strategy the firm uses in the market. According to the Total Quality Model developed at the Nordic School of Services (Gummesson, 1993), perceived quality is essentially a function of the impression of two sizes: the impact of the outcome or the technical solution (what the user gets) and the additional influence that is based on the impression of the user about different interactions with the firm (how something is gained). The first size of quality is called technical quality and the second is the functional quality of the interaction process. The principle of transaction marketing does not include any (or minimal) contact with users outside the product and other variable sizes of 
the marketing mix. Benefits generated by customers are built into the technical solution provided. The user won't get much more than that, except maybe the value of the company image or brand. Therefore, technical product quality, or what is obtained as a result of production, is the dominant source of quality creation in transactional marketing.

In relationship marketing, the situation is different. The connection with customers is wider, and the company has the ability to provide its customers with additional value of different types (technological, information, professional, social, etc.). Therefore, the second quality dimension, related to how the interaction process is observed, is given greater importance. When several firms can provide similar technical quality, managing the interaction process becomes imperative, also from a quality perception perspective.

In such conditions, the dimension of functional quality in relationship marketing is gaining in importance and often becomes dominant. Of course, this does not mean that technical quality should be neglected, but it no longer represents a dimension that is considered strategically relevant. An easy way to monitor customer satisfaction and success is to monitor market share and to conduct occasional market research. Stable and growing market share is considered a measure of success, and therefore indirectly, of customer satisfaction. Market share is an adequate measure of customer satisfaction when the customer base remains unchanged. However, it is often not known whether the customer base is the same or the company is losing customers, and replacing them with aggressive marketing and sales with new ones.

In these situations, monitoring market share statistics can easily give the wrong impression of success, because, in fact, the number of dissatisfied users and former users is growing, the image of the company is declining, and this is not reflected in the statistics. A firm that implements a relationship strategy can monitor customer satisfaction by directly managing the customer base. Managing a customer base means that the company has some direct knowledge of how satisfied its customers are. Instead of thinking about anonymous numbers, or market share, management thinks about people with personal reactions and attitudes. This requires some special way of collecting different types of data from users, which is constantly received every day through a large number of employees in direct contact with users. Combined with market share statistics, an information system that focuses on meeting the needs and desires of users is a valuable source of information for business decision making. Consequently, in the context of marketing relationships, a firm can create and use an information system that would continuously update management information about its customers and provide continuous information on the extent to which they are satisfied.

\section{FUTURE RESEARCH DIRECTIONS}

Considering the analyzed characteristics of rural regions in Serbia, the dominant causes of their slow development are: migration of rural population to urban areas, unfavorable age structure, under-investment in rural areas, identification of agriculture with rural development with insufficient involvement in non-agricultural activities, etc. These regional areas have specific regional characteristics and different stages of rural development, and it is appropriate to take a situational or regional approach into account when defining support measures. Accordingly, in line with the specific needs of individual rural regions, it is necessary to further explore the possibilities of building regional and local institutions to support the development of rural tourism while enhancing the cooperation of the Ministry of Agriculture with local governments. It 
is also necessary to increase investment in rural development while directing support towards diversification of activities in rural areas of Serbia.

The vision for rural areas in Serbia implies the development of more propulsive and competitive agriculture composed of commercial and family farms that are exclusively engaged in agriculture and/or engaged in rural tourism in terms of an additional source of income. However, the desired future in this area will not be destroyed by itself or because it is fervently desired. The desired future and the achievement of the strategic goals of the Republic of Serbia within the Danube region require immediate action. The future of rural tourism and rural development in Serbia is, to a lesser extent, a function of available resources and geographical location, and more of a strong leadership and effective rural development strategy.

\section{CONCLUSIONS}

In recent years there has been a gradual loss of authenticity of well-known tourist centers. Considering the growth of tourist demand and the high price of services in these centers, there is a need for a planned direction of demand towards other parts of tourist-attractive rural areas. The activation of tourist potentials of these destinations can significantly contribute to faster overcoming of economic backwardness. An important role in the development of rural tourism in Serbia could play a small business. The process of creating partial tourism programs deserves financial support. Lack of an integrated tourist offer makes it difficult to apply marketing and management approaches to rural tourism development at the national and local levels and this must be given special attention in the future.

Accordingly, in accordance with the specific needs of individual rural regions, it is necessary to support the construction of regional and local institutions to support the development of rural areas while enhancing the cooperation of the Ministry of Agriculture with local governments. It is also necessary to increase investment in rural development while directing support towards diversification of activities in rural areas of Serbia.

There is no universal rural development program today, because this plan depends on various factors that affect it. Some of these factors are the physical, demographic and economic characteristics of each particular zone. The development of the zone will be different depending on the stage in which the depopulation is at a critical level in relation to the zone where this situation is not. The development of rural areas can increase the employment of the population and its standard. Revitalizing rural settlements and paying more attention to rural tourism can slow down the decline in agricultural settlements. It is precisely for the purpose of revitalizing rural settlements that integral programs of rural economy development are enacted. Integrated rural development programs should prevent an urban exodus in Serbia in the future.

\section{ACKNOWLEDGEMENT}

Paper is a part of research within the project no. III 46006 - Sustainable agriculture and rural development in the function of accomplishing strategic objectives of the Republic of Serbia in the Danube region, financed by the Ministry of Education, Science and Technological Development of the Republic of Serbia, project period: 2011-2019. 


\section{REFERENCES}

Bogdanov, N. (2007). Small Rural Households in Serbia and Rural Non-Farm Economy. UNDP, Belgrade.

Bojnec, S. (2010). Rural Tourism, Rural Economy Diversification, and Sustainable Development. Academica Turistica - Tourism and Innovation Journal, 3(1-2), 7-15.

Cvejić, S., Babović, M., Petrović, M., Bogdanov, N, \& Vuković, O. (2010). Social exclusion in rural areas of Serbia. UNDP. Belgrade [in Serbian: Cvejić, S., Babović, M., Petrović, M., Bogdanov, N, \& Vuković, O. (2010), Socijalna isključenost u ruralnim oblastima Srbije].

Cvijanović, D., Cvijanović, G., Pušakrić, A. (2011). Marketing and ecological farming, IAE, Belgrade [in Serbian: Cvijanović, D., Cvijanović, G., Pušakrić, A. (2011), Marketing i ekološka poljoprivreda].

Cvijanović, D., Mihailović, B., \& Paraušić, V. (2012). The rural development policy of EU in context of improving rural areas of Serbia. Thematic proceedings Rural areas and development, vol. 9, 7-25. ERDN, Institute of Agricultural and Food Economics, Warsaw, Poland, Institute of Agricultural Economics, Belgrade

Cvijanović, D., Vuković, P. (2012). The role of marketing in tourism in the Danube region of Serbia, IAE, Belgrade [in Serbian: Cvijanović, D., Vuković, P. (2012), Uloga marketinga u turizmu dunavskog regiona Srbije].

Cvijanović, D. (2014). Tourism market in the Danube region, IAE, Belgrade [in Serbian: Cvijanović, D. (2014), Turističko tržište u dunavskom regionu].

Cvijanović, D., Mihailović, B., Vukotić, S. (2016). Marketing and consulting in the function of tourism development in Serbia, IAE, Belgrade [in Serbian: Cvijanović, D., Mihailović, B., Vukotić, S. (2016), Marketing i konsalting u funkciji razvoja turizma Srbije].

Čomić, Lj. (2002). Rural tourism in Serbia - opportunities and perspectives. Tourism, 6, 119-120 [in Serbian: Čomić, Lj. (2002), Ruralni turizam u Srbiji - mogućnosti i perspektive].

Đorđević Milošević, S., \& Milovanović, J. (2012). Sustainable tourism in the function of rural development: Small farms and rural tourism in Serbia. Faculty of Applied Ecology Futura, Belgrade, Agroznanje Vršac, FAO Budapest [in Serbian: Đorđević Milošević, S., Milovanović, J. (2012), Održivi turizam u funkciji ruralnog razvoja: Mala poljoprivredna gazdinstva i ruralni turizam u Srbiji].

European Federation of Rural Tourism - Eurogites, Retrieved from https://www.eurogites.org/ countries/ (14. 05. 2019).

GlobalG.A.P. Cultivating the Future of the Planet, Retrieved from https:/www.globalgap.org/ uk_en/for-producers/globalg.a.p./ (27. 05. 2019).

Gummesson, E. (1993). Quality Management in Service Organizations, ISQA (International Service Quality Association), New York, NY.

Hopić, S. (2010). Rural Development in the Republic of Serbia. SKGO, Exchange2 Joint Support to Local Governments [in Serbian: Hopić, S. (2010), Ruralni razvoj u Republici Srbiji].

Hyvaerinen, K. (2019). Rural tourism \& EU economic diversification policies. Regional Expert Advisory WG on Economic Diversification through Rural Tourism, Skopje, 24. 01. 2019, Retrieved from http://seerural.org/wp-content/uploads/2019/02/ Annex-10-Rural-tourismand-EU-policies.pdf.

IPARD Program for the Republic of Serbia 2014-2020, Official Gazette of the RS, no. 30/16, 84/17, 20/19 [in Serbian: IPARD program za Republiku Srbiju za period 2014-2020. godine, Službeni glasnik RS, br. 30/16, 84/17, 20/19].

Jovićević Simin, M., Jovićević, P., \& Novaković, S. (2016). Appellations of geographical origin as a generator of national competitiveness. Economics of Agriculture, 63(2), 567-583. 
Law on Tourism, Official Gazette of the RS, no. 17/19 [in Serbian: Zakon o turizmu, Službeni glasnik RS, br. 17/19].

Law on Food Safety, Official Gazette of RS, 41/09, 17/19 [in Serbian: Zakon o bezbednosti hrane, Službeni glasnik RS, br. 41/09, 17/19].

Mihailović, B., Cvijanović, D., \& Paraušić, V. (2012). Analysis of economic performance of rural regions of Serbia. Proceedings of the Institute Agroekonomik, Belgrade, 109-119 [in Serbian: Analiza ekonomskih performansi ruralnih regiona Srbije].

Mihalović, B., Simonović, Z. (2016). Strategic planning of sustainable development of agriculture and rural areas in Serbia, IAE, Belgrade [in Serbian: Mihalović, B., Simonović, Z. (2016). Strateško planiranje održivog razvoja poljoprivrede i ruralnih područja u Srbiji].

Mihailović, B., \& Popović, V. (2018). Management of service marketing: a perspective of modern tourism sector. In Modern management tools and economy of tourism sector of the present era. Association of Economists and Managers of the Balkans, Belgrade, Faculty of Tourism and Hospitality, Ohrid, 143-158.

Ministry of European Integration (MEI). General information about cross-border cooperation programmes, Retrieved from http://www.evropa.gov.rs/CBC/Public Site/Default. aspx (27.05.2019).

Ministry of European Integration (MEI). (2018). National program for the adoption of EU acquis. Third revision.

Ministry of Agriculture, Forestry and Water Management (MAFW) (2019). IPARD II, Call Plan for 2019, Retrieved from http://uap.gov.rs/wp-content/ uploads/2017/11/IPARD-II-programPlan-poziva-za-2019.pdf [in Serbian: Ministarstvo poljoprivrede, šumarstva i vodoprivrede (2019), IPARD II, Plan poziva za 2019. godinu].

National Rural Development Program (NRDP) 2018-2020, Official Gazette of the RS, no. 60/18 [in Serbian: Nacionalni program ruralnog razvoja od 2018. do 2020. godine, Službeni glasnik RS, br. 60/18].

National Rural Development Program 2011-2013, Official Gazette of the RS, no. 15/11[in Serbian: Nacionalni program ruralnog razvoja od 2011. do 2013. godine, Službeni glasnik RS, br. $15 / 11]$.

Pejanović, R. (1993). Economic development - ecological crisis and the position of agriculture. Agroeconomics, Faculty of Agriculture, Novi Sad, 20-32 [in Serbian: Pejanović, R. (1993). Ekonomski razvoj - ekološka kriza i položaj poljoprivrede].

Popović, V., Vuković, P., \& Ćosić, M. (2017). Food Safety and Quality Policy in the Republic of Serbia. Economics of Agriculture, 64(4), 1607-1617.

Popović, V., Milijić, S., \& Vuković, P. (2012). Sustainable tourism development in the Carpathian region in Serbia. SPATIUM International Review, 28, 45-52.

Popović, V., Nikolić, M., \& Katić, B. (2010). The role of multifunctional agriculture in sustainable tourism development in the area of Stara Planina. Economics of Agriculture, 57(SI-2), 333-342.

Popović, V., Nikolić, M., Živanović Miljković, J., \& Jovanović, B. (2009). Multifunctional agriculture and rural development in Mediterranean conditions. IEP, Beograd [in Serbian: Popović, V., Nikolić, M., Živanović Miljković, J., \& Jovanović, B. (2009). Multifunkcionalna poljoprivreda i ruralni razvoj u mediteranskim uslovima].

Program for the development of sustainable rural tourism in the Republic of Serbia, Official Gazette of the RS, no. 85/11 [in Serbian: Program razvoja održivog ruralnog turizma u Republici Srbiji, Službeni glasnik RS, br. 85/11].

Regulation on conditions and method of allocation and use of credit funds for promotion of the quality of tourist offer, Official Gazette of the RS, 6/19 [in Serbian: Uredba o uslovima i 
načinu dodele i korišćenja kreditnih sredstava za podsticanje kvaliteta turističke ponude, Službeni glasnik RS, br. 6/19].

SEEDEV. (2014). To add value to products. FAO, EBRD, Agrikultura [in Serbian: SEEDEV. (2014), Dodati vrednost proizvodima].

Serbia Organica. (2019). Organic production in Serbia, Retrieved from https:// serbiaorganica. info/organska-proizvodnja-u-srbiji/ (12. 05. 2019) [in Serbian: Serbia Organica. (2019) Organska proizvodnja u Srbiji].

Social Exclusion In Rural Areas In Serbia, UNDP, 2010.

Šimičević, D., \& Štetić, S. (2011). Importance of local agriculture sales through specialized gastronomic products. Economics of Agriculture, 58(SB-1), 255-264 [in Serbian: Šimičević, D., \& Štetić, S. (2011). Značaj plasmana lokalne poljoprivrede kroz specijalizovane gastro turističke proizvode].

The ECRT. 6th European Congress on Rural Tourism Internationalization of Rural Tourism, Druskininkai, Lithuania, 3-5 October, 2018, Retrieved from http://www.europeanrtcongress.org/about-this-congress_798737041_58128.html.

Tourism Development Strategy 2016-2025, Official Gazette of the RS, no. 98/16 [in Serbian: Strategija razvoja turizma 2016-2025, Službeni glasnik RS, 98/16].

UN Joint Programme (UNJP) in Serbia. (2011). Master Plan for sustainable development of rural tourism in Serbia. UNJP Sustainable Tourism for Rural Development Workshop, 8. 04. 2011, Retrieved from https://www.slideshare. net/kreativnacarolija/master-plan-ruralnog-turizma [in Serbian: UNJP in Serbia. (2011), Master Plan održivog razvoja ruralnog turizma Srbije].

UNWTO. (2017a): Report of the Secretary-General. Part I(a): Implementation of the general programme of work for 2016-2017. Annex II. 22nd Session of the General Assembly Chengdu, China, 11-16 September 2017, A/22/10(I)(a) rev.1.

UNWTO. (2017b): Resolutions adopted by the General Assembly at its 22nd Session. Part I(a): Implementation of the general programme of work for 2016-2017, Chengdu, China, 11-16 September 2017, A/RES/684(XXII).

Vojnović, V. (2012). Soulfood Serbia. National Tourism Organisation of Serbia, Belgrade.

Vujović, S., Cvijanović, D., \& Štetić, S. (2012). Destination concept of tourism development, IAE, Belgrade [in Serbian: Vujović, S., Cvijanović, D., \& Štetić, S. (2012), Destinacijski koncept razvoja turizma].

Vuković, P. (2017). Character and dynamics of development rural tourism in the Republic of Serbia. Ekonomika, 63(4), 53-60.

Vuković, P., Popović, V., \& Arsić, S. (2016). State and condition for implementing ICT in rural tourism in the Republic of Serbia. Proceedings of the $152^{\text {nd }}$ EAAE Seminar Emerging Technologies and the Development of Agriculture. SAAE, Faculty of Economics, Subotica, IAE, Belgrade, 257-275. 